\title{
Praxis of linguistics: Passives in Dutch*
}

ARIE VERHAGEN

\section{Abstract}

- This paper examines the two major forms of passives in Dutch: with the auxiliary worden 'to become', and with zijn 'to be'. In contrast to traditional approaches, it takes the view that this usage is related to other uses of the

- verbs (i.e. passives are viewed as analyzable). This provides a natural framework for an integrated description of standard and "non-standard" forms of passives. More importantly, it explains a striking difference in actual usage that has not been taken into account before: it is specifically the wordenpassives that give rise to problems of usage in texts and in writing classes. This paper claims that worden, being inchoative with respect to zijn, presents a state (denoted by the participle) as coming about, while zijn simply presents the existence of a state. Consequently, a worden-passive presents a situation from a perspective other than that of a participant that is implied to be present in this situation (the agent), and this often results in an effect of deliberate backgrounding. In a zijn-passive, the agent is not implied to be

- present in the situation described (a state), so that no special effects result from the fact that it is not chosen as the entity from whose perspective the situation is presented. Furthermore, the idea that different degrees of detransitivization are involved suggests new ways in which problematic usage of passives in texts may be avoided - i.e. solutions to problems that traditional grammatical approaches to composition have been unable to deal with.

The cognitive linguistic idea of analyzability of a grammatical construction can thus be successfully applied to practical problems; this provides a specific type of empirical support for the approach, which is to be welcomed in view of a number of methodological and philosophical considerations.

\section{Introduction}

In history and philosophy of science it is at present more or less a commonplace to say that facts do not decide between scientific theories 
for us. Especially since the seminal work by Thomas Kuhn (Kuhn 1970) it has become very clear that scientists do not make that kind of choice on the basis of the facts clearly deciding against one theory and in favor of another; for example, "crucial experiments" are in general devised and conducted only some time after a scientific community has adopted a new "paradigm". Still, when we look at choices scientists actually made, such as preferring a Galilean picture of the universe over an Aristotelian one, we do not want to say that they were behaving completely irrationally; thus there is a question: how can we understand that behavior as rational if not in terms of the scientists just acknowledging the facts? The answer is that scientific theories are not correct or distorted reflections of the world, but rather tools, instruments for solving problems (cf. Laudan 1977: 5); in the case of the natural sciences for example: the problems involved in predicting and controlling the world, specifically as represented in experiments. Choosing a scientific theory is, then, choosing a tool that serves certain purposes better than other, previous tools. This view has been elaborated by a number of historians and philosophers of science. A clear formulation has recently been given by Richard Rorty. In his words, Galileo should not be seen "as making a discovery - finally coming up with the words which were needed to fit the world properly, words Aristotle missed", but rather

as having hit upon a tool which happened to work better for certain purposes than any previous tool. Once we found out what could be done with a Galilean vocabulary, nobody was much interested in doing the things which used to be done (and which Thomists thought should still be done) with an Aristotelian vocabulary. (Rorty 1989: 19)

To give a concrete parallel: choosing between theories may well be viewed like choosing between a typewriter and a personal computer with a word processing program. Such a choice is not an empirical matter; there are no facts dictating one choice over the other. But it is still rational for people, at least in many circumstances, to prefer the computer over the typewriter, and after some time, typewriters are just no longer used. In the same way, old scientific theories are gradually abandoned, not so much because the facts show them to be incorrect reflections of the world, but because there are other instruments doing a better job. Thus, choosing a particular scientific paradigm is not an empirical matter, but that does not mean that the choice would be arbitrary, that choices are without consequences external to the theories themselves.

However, when we try to match this general picture with the situation in linguistics, we are faced with a problem: What exactly is it that can be done with one theory as opposed to another? What are the external 
consequences of a linguistic theory? What are the purposes for which it is a tool? It seems that the situation in linguistics is special in that there are no clear answers to these questions. Or rather: that there are no longer answers to them. Until some time in the nineteenth century linguistics was intimately tied up with the pursuit of a number of external goals: the teaching of languages, text analysis, the development and teaching of rhetoric, philosophical analysis, and other such activities. For reasons that need not concern us here, linguistics was separated from these other fields, which, to linguistics, were fields of application. As a consequencegiven that the world does not decide between theories - the field gave up the only practicable rational way of making such choices. ${ }^{1}$ What I want to claim now is that cognitive/functional linguistics is in the position to restore the bond between linguistic theorizing and the pursuit of external goals. That is, cognitively and functionally oriented schools in linguistics, because of the kind of problems they are concerned with, and the way they approach these problems, can contribute to certain very useful goals outside their own immediate domain as approaches to the study of language; and by that, they can create support for the general approach that can be very important in a situation of theory choice. ${ }^{2}$

Some areas where cognitive/functional linguistics can be usefully applied have already begun to emerge; some examples are Chilton and Lakoff's (1989) application of the theory of metaphor to the analysis of political discourse, and Turner's (1987) work in the field of literary criticism; also, the prototype approach to lexical semantics can be usefully - applied in lexicography: it provides an instrument for writing more insightful dictionary entries for non-synonymous elements with partly overlapping uses than would otherwise be possible (for an example, cf. Geeraerts 1988 and, more specifically, Geeraerts 1985b). To these examples I want to add the possibility of applying a cognitive approach to grammar to the field of teaching "advanced" language use to native speakers, in particular teaching the use of language in expository writing. ${ }^{3}$ Such situations can be viewed as situations in the world of actual language use which we can try to handle better than we did before, using linguistic theory as an instrument; i.e., in some respects, as situations of experimentation.

Relating linguistics to such external goals can open up new empirical domains: to the extent that applications meet problems, these should seriously be considered as potential problems for linguistic theory and not be dismissed a priori as problems of performance. Perhaps more importantly, to the extent that such applications are successful they provide support for the theoretical approach, and stronger support than "fitting the facts" could ever provide. It is in this perspective that the 
analysis of Dutch passives in this paper is presented: as an example of an analysis that is on the one hand informed by problems external to linguistics proper, and that, on the other hand, provides support for the general cognitive/functional approach within which the analysis is undertaken, because of its successful application to an external problem (in this case involving teaching composition). Methodologically, relating success of an approach to this kind of external problems amounts to an extension of the class of "external" problems acknowledged by Laudan (1977). ${ }^{4}$

The possibility of such new empirical domains is also to be welcomed for reasons internal to cognitive linguistics, especially in view of its conception of grammatical rules. I follow Langacker $(1988,1990)$ in taking grammatical rules (or "schemas") to be abstracted from specific instances of usage, which may at the same time have the status of units. There is a schema, for example, for plural nouns in English, with " $\mathrm{x}-\mathrm{s}$ " as its formal side, and "more than one X" as its semantic side, but its existence does not exclude that a speaker/hearer has plural nouns like dogs and trees also available as units (the schema identifies particular cases as instantiations of the schema). On the other hand, the plural dogs, even when available as a unit, is still also analyzable (with respect to some aspects of its meaning, identified by the schema as shared between this word and others). Knowledge of language cannot be sharply divided into knowledge of units on the one hand, and knowledge of rules on the other, in the sense that they would correspond to strictly distinct ranges of linguistic phenomena.

Useful and realistic though this approach is, it does present a methodological problem: if both knowledge of a unit as such and knowledge of a schema analyzing it may underlie one's understanding of an expression, how are we to justify a particular schema-analysis? The answer can no longer be that it accounts for a native speaker's judgements, for those might just as well be accounted for in terms of (a list of) units. The answer must involve differentiation of the usefulness of units from that of schemas.

While knowledge of a particular instance as a unit is especially useful for fast understanding of new occurrences of the same expression (like grasping the value 144 of the familiar arithmetic expression $12 \times 12$ "at once"), knowledge of a schema is useful as a basis for an attempt to understand an expression that is relatively novel or in another way "problematic". If someone does not fully understand an expression, for example because of lack of experience, s/he may try to use a schema to improve his/her understanding (like reaching the same value 144 "step by step" when the expression is in some way problematic, e.g. by multiply- 
ing 10 by 12 and 2 by 12 and adding the results). Analogously, if someone shows poor understanding by using some expression in a wrong way, someone else may appeal to a schema to improve the other person's understanding and subsequent use of the language. Consequently, such situations of language explication and language learning provide a domain of empirical evidence especially for hypotheses about schemas, evidence that could not be forthcoming in the same way from intuitive judgements only. The approach to Dutch passives to follow therefore also provides an illustration of this methodology.

A final methodological remark is in order here: even if a linguistic analysis is undertaken for the purpose of application (as the present one is), it still does not constitute the application by itself (one does not teach the use of an aspect of language by presenting learners with a "correct"

- theory of that aspect). For one thing, whereas a linguistic analysis focuses on a particular construction, teaching language use in composition always involves several aspects of language at the same time. As is well known from writing courses, for example, problems in the use of the passive tend to correlate with other problems, such as the extensive use of nominalizations (also allowing non-mentioning of an agent); this paper, presenting a linguistic analysis, does not address all possible issues relevant to an adequate composition course, but only an analysis of Dutch passives aimed at contributing to such a course. However, when a course incorporating this contribution proves to be successful, we may take this as supporting evidence for the analysis - and we will review some evidence of that nature towards the end of this paper.

\section{Two periphrastic passives in Dutch}

Modern Germanic languages all have periphrastic passives employing the verb "be" and/or cognates as passive auxiliaries. In several respects, the possibilities for forming passive and passive-like constructions in these languages also differ; for example, Swedish has retained a morphological passive ( $s$ suffixed to a verb stem) for certain usages, (spoken) English uses the verb get as a passive auxiliary, Dutch employs krijgen ('to get, to receive') to form indirect object passives (Zij kreeg een leuke baan aangeboden 'She was offered a nice job'). But the formation of a 'be'like auxiliary verb and a past participle is a general option for forming passive sentences in all these languages. Now English uses only the verb be itself but Dutch and German employ both zijn/sein ('to be') and worden/werden (literally: 'to become'), the latter being the obligatory form in the simple tenses (when the passive auxiliary is finite), i.e. where 
English uses a form of be. We will see that the differences and similarities between these two forms in Dutch can be motivated in terms of the contributions that the elements of which they consist make to the overall meaning of the sentence, i.e. in terms of them being analyzable in different ways.

This paper will deal exclusively with these two most general forms of the passive. The main reason is their very generality: these passives are the only ones that can occur so frequently in relatively short spans of texts that they can contribute significantly to the character of the text as a whole. Standard grammars in fact label these as the forms of the "passive" (cf. ANS 1984: 525); the indirect object passives formed with krijgen have such a specific use that their frequency in the written language is only a fraction (in the order of $1 \%$ in the Eindhoven Corpus, described in Uit den Boogaart 1975) of that of the standard types of passive (for a description, drawing interesting parallels with other, non-passive constructions involving the past participle, see ANS 1984: 529). Another, but related reason for not treating the krijgen-passives here is that their use (precisely because of its specificity) for native speakers hardly ever leads to problems in composition, and never to problems concerning the general character of the text, whereas the use of the other passives - in particular the worden-passives, as we will see later - regularly does; of course, it would definitely be an interesting topic, also with potential practical consequences, for foreign learners of Dutch who wish to speak as idiomatically as possible. Finally, important as it may be for an actually working composition course, this paper (given its primary purpose of providing a linguistic analysis) does not go into all kinds of constructions that may have effects similar to that of the passive.

The two standard forms for the passive in Dutch, then, are: 1) some form of worden ${ }^{6}$ combined with a past participle, and 2) some form of zijn with a past participle. Grammars describe the difference between these two forms in terms of tense: zijn + participle is said to constitute the perfect tense of worden + participle. The rule generally given is: present and past of non-perfect passives are formed with worden, present and past of perfect passives are formed with $z i j n ;^{7}$ schematically:

passive in simple present and simple past: worden (lit.: "to become') + past participle passive in present and past perfect: zijn ('to be') + past participle

Since Dutch does not have (a grammaticalized use of) the progressive form, ${ }^{8}$ the form worden + participle corresponds to both English be + participle and are being + participle; the description by the grammars 
on the other hand implies that the forms with zijn correspond only to have been + participle, i.e. the perfect of the passive in English. This view is also that generally found in textbooks on English for Dutch learners (for example, Brederode et al. 1990: 100). It can be represented schematically as follows:

$\begin{aligned} \text { Non-perfect, present: } & \begin{array}{l}\text { worden gezongen ('are sung', 'are being sung') } \\ \text { be(come) sung }\end{array} \\ \text { past: } & \begin{array}{l}\text { worden gezongen ('were sung', 'were being sung') } \\ \text { be(came) sung }\end{array} \\ \text { Perfect, present: } & \begin{array}{l}\text { zijn gezongen } \\ \text { are sung }\end{array} \\ \text { past: ('have been sung') } & \text { waren gezongen ('had been sung') } \\ & \text { were sung }\end{aligned}$

- However, in actual usage things are more complicated than this schema suggests; or rather, they may be simple, but in a way that is different from this traditional picture. As a start, consider the question of how the Dutch passives are to be translated into English. The point is first that, contrary to what the picture presented suggests, zijn + participle is not always to be translated into English with have been + participle; secondly, worden + participle cannot always be rendered equally well by are being + participle as with $b e+$ participle, again contrary to the suggestion from the traditional view. The problem can be nicely illustrated by means of the examples in the following quotation from Turner (1973: 93-94):

Passive constructions are normally ambiguous in aspect. In 'The old songs are all sung now', the word are could be replaced by have been, but not in 'The old songs are sung with a modern accompaniment'. If we encounter 'The floor is polished' in isolation, we do not know whether the reference is to a process ('The floor is polished every morning') or a condition of the floor ('Walk carefully; the floor is polished'). An interesting use of this inbuilt ambiguity in the passive is made by Gwyn Jones in his translation of Hrafnkels Saga. The text tells us that people were settling eastern Iceland at the time of the story, but historians have pointed out that it is unlikely that the settlement continued so late. Jones translates: 'Most of the land in the district was settled in Hrafnkel's days' - a tactful solution.

In recent but not in older English, an unambiguously imperfective or continuous passive is available ('The songs are being sung'). But this form is odd in not contrasting with an unambiguously perfective form. It is a newcomer to the language, not yet part of a symmetrical system of aspect.

In (1) through (6) Turner's examples are given with their Dutch translations: 
(1) a. The old songs are all sung now

b. The old songs have all been sung now

(2) The old songs are sung with a modern accompaniment

(3) The floor is polished every morning

(4) Walk carefully; the floor is polished

Most of the land was settled in Hrafnkel's days

The songs are being sung

De oude liederen zijn $n u$

allemaal gezongen

De oude liederen worden gezongen met moderne begeleiding

De vloer wordt elke morgen gepoetst

Voorzichtig lopen: de vloer is gepoetst

Het grootste deel van het land was/werd gekoloniseerd in de dagen van Hrafnkel

De liederen worden gezongen

When we consider only the passive construction as such, abstracting away from disambiguating context, the total set of options can be represented in the following two schemas:

Dutch from the English point of view:

worden gezongen -are sung

-are being sung

zijn gezongen -are sung

- have been sung

English from the Dutch point of view:

are sung

are being sung

have been sung -worden gezongen

-zijn gezongen

-worden gezongen

-zijn gezongen

This overview shows that, in terms of tense, an English non-perfect passive is sometimes to be translated as a perfect passive in Dutch (cases la and 4). Turner states the well-known fact that a phrase like is polished is ambiguous between a process-reading as in (3) and a state-reading as in (4), a so-called statal passive. Dutch seems to lack this ambiguity: the process-reading is to be translated with worden, the state-reading with zijn. This corresponds to the facts that when a paraphrase with have been is possible in English (case 1), the Dutch translation is with zijn, and when English has a progressive (case 6), the Dutch translation must make 
use of worden. So we might be tempted to think that Dutch simply lacks the ambiguous form of English, as indicated in the following schema:

Dutch and English in one diagram:

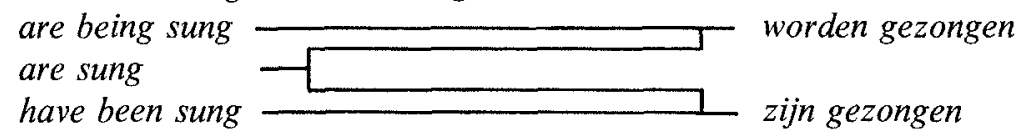

However, if that were all there was to it, this would imply that it should always be possible to translate a worden-passive adequately with a progressive form in English and zijn with the perfect of the passive (have been), but this does not seem to be the case. For example, the English part of example (2) above is not very well paraphrased with a progressive; that would invoke too much the idea of one actual performance, being witnessed at the moment of speaking, and it would completely lose the idea of a general statement (perhaps a prescription) that is suggested by both the English and the Dutch originals.

Something similar holds for the perfect. It is true that in the translation into Dutch of example (5) a choice must be made between worden and $z i j n$, but that does not mean that the ambiguity is completely resolved. Although the version with werd is not ambiguous with respect to the time of the settlement (it being Hrafnkel's days), the version with was still is: as in the English case, the settlement could have taken place in Hrafnkel's days, or it could already have been completed then (in terms of the analysis in Janssen in press: the time adverbial may either modify the time of the finite verb, or that of the participle, respectively).

It should come as no surprise, then, that from the point of view of the grammar of English, one may also very well state that it is the Dutch $z i j n+$ participle construction which is ambiguous between the perfect of the passive and the simple present/past of the passive (or a statal passive); this is the position taken, for example, by Aarts and Wekker (1987: 275), in discussing the possible English translations of the Dutch Hij wist dat het lijk in de tuin begraven was as either "He knew that the body had been buried in the garden" or "He knew that the body was/lay buried in the garden".

It is clear that the resolution of these problems at least partly depends on an analysis of the English verbal system, in particular of the perfect and the progressive, which is beyond the scope of this paper; but the above considerations nevertheless suffice to make it clear that the resemblance between the English be-and the Dutch zijn-passive is greater than the standard analysis would allow for, and that it is not "perfect" as only a tense category that provides the best means for understanding the 
function of the different passive forms (even if in a specific case the best way to explicate the difference between a case of worden and a case of zijn would be in terms of tense, it is clear that this is not going to be a general explanation in any way). In particular, it is clear that in both languages the simple combination of the auxiliary meaning 'be' with a past participle is the best formulation for evoking a stative meaning, without any 'extra' suggestions about some process bringing it about. It is this relation between stativity and the passive, especially the relation between choice of passive auxiliary and degree of stativity, that will turn out to be particularly important in the analysis of the passive in Dutch. Briefly: the worden-passive will be shown to evoke some notion of "change" (due to the meaning of the auxiliary) and therefore to be less stative than the $z i j n$-passive, in which the notion of "change" may be completely absent.

\section{Problems of usage in composition}

\subsection{Practical and theoretical views of the function of the passive}

For my analysis of the function of passives in Dutch, I will take my point of departure in a problem that is "experimental" in the sense of section 1 , viz. the treatment of the passive in composition courses.

All kinds of composition courses, for example for college freshmen or for government officials, pay attention to the passive, and rightly so, for many (novice) writers of expository prose often use the passive inadequately. In most cases the problem manifests itself in a proliferation of passive clauses in the texts of these writers. In order to be able to talk about this problem to these writers in a composition course, one needs certain notions to characterize the possible effects of the passive in texts. One needs certain concepts in order to explain that the use of the passive may have a certain effect (sometimes undesirable) on the interpretation of a text. Such concepts are, in effect, grammatical notions.

Accordingly, composition courses do indeed provide grammatical characterizations of the passive to that end. Two textbooks for composition very widely used in The Netherlands are Overduin (1986) and Renkema (1979) (the latter completely revised in 1989), and they are largely in agreement about the function of the passive: it is to "background" or "de-emphasize" the agent of an action, in order to foreground something else, specifically the object, or the action itself (Overduin 1986: 179, 180; Renkema 1979: 39; Renkema 1989: 95; cf. Verhagen 1990: 82). This characterization accords with the standard one in grammars of Dutch 
(cf. ANS 1984: 1050, 1054), which is in turn indebted to Kirsner's (1976a, 1976b) analysis of the Dutch passive. The core of this analysis is the meaning proposed by Kirsner for the passive, viz.: "High participant not in focus", i.e.: a relatively active, agent-like participant is not in the focus of the speaker's attention. ${ }^{10}$

What we see, then, is widespread agreement among writers of composition textbooks, general grammarians, and specialists, on the general terms in which to describe the function of the passive in Dutch. I do not want to argue that this approach is completely mistaken, but in the practice of teaching writing it nevertheless presents a number of problems to teachers and students. I now want to address these problems in more detail, from a linguistic point of view, and use them as arguments for , another kind of analysis; this analysis will incorporate what is useful in the traditional approach, but it will nevertheless emphasize rather different aspects of the passive than is customary.

\subsection{Transformational stylistics}

The first problem is the one-sidedness of the analysis of "de-emphasizing the agent": it focuses exclusively on the relation (i.e. the difference) between passive sentences and their active counterparts. This becomes especially apparent when the authors weigh passives against other ways of formulating a message: time and again it is the direct active counterpart "that is presented as the preeminent alternative to a passive sentence. Because of this feature, I call this approach "transformational stylistics".

Overduin (1986: 180-184) typically provides only pairs like (7) to illustrate the effect of using a passive formulation (in these and other examples, the elements of the passive construction are non-italicized):

(7) a. Een aantal aanpassingen in de administratieve organisatie moet worden doorgevoerd, voordat ...

'A number of adaptations in the administrative organization must be carried through before ...'

b. $U$ moet een aantal aanpassingen in de administratieve organisatie doorvoeren, voordat ...

'You have to carry through a number of adaptations in the administrative organization before ...'

What this leads to can be seen in (8) and (9); (8) is a typical example of "officialese", or "bureaucratese", clearly containing an overdose of passives; so I agree with Overduin that a passage like (8) should be rewritten. 
(8) Wanneer het voertuig wordt bestuurd door een minderjarige, wordt door de verzekeringsmaatschappij verplicht gesteld dat de polis wordt ondertekend door de ouder of toeziend voogd, waarbij aangenomen wordt dat de richtlijnen van formulier 3 onverkort nageleefd worden. 'When the vehicle is driven by a minor, it is required by the insurance company that the policy is signed by the parent or guardian, in which case it is assumed that the directives of form 3 are observed without any restriction.'

But now observe the revision Overduin recommends:

(9) Wanneer een minderjarige het voertuig bestuurt moet de ouder of toeziend voogd de polis ondertekenen. De verzekeringsmaatschappij verplicht hiertoe. Verder neemt de verzekeringsmaatschappij aan dat. men de richtlijnen van formulier 3 onverkort naleeft.

'When a minor drives the vehicle the parent or guardian has to sign the policy. The insurance company requires this. In addition, the insurance company assumes that one observes the directives of form 3 without any restriction.'

I contend that in fact this is also far from optimal. For example, the information about being a minor is undoubtedly new, and it probably contrasts with information in the preceding part of the text, but in the revision it is positioned at the beginning of its clause. Furthermore, there is little thematic cohesion between the first and the second sentence, i.e. no topic continuity, and no immediate connection between the end of the first and the beginning of the second clause; as is well known, passive is often used precisely for such reasons of thematic cohesion (cf. Van Oosten 1986: 137, 139): by preventing the agent from becoming the. subject, the passive may allow for a useful other way of construing thematic relations between sentences. Finally, some readers find reason for being amused by the first clause because it is easily read as a time adverbial, indicating that at the time a minor drives the car, someone must sign the policy.

So it is not really surprising that students in writing courses often protest (as they in fact do) against such rewriting proposals. They do not feel much helped by this advice, and I think they are quite justified in this feeling.

Another problem concerns the use of the notions "emphasis" and "attention" in the grammatical characterization of the passive. In completely natural sentences like (10) through (12) there is, in a most ordinary sense of the words, much emphasis on and attention to the agents: ${ }^{11}$

De aanzet tot het NMP werd in 1986 gegeven door de toenmalige 
minister van VROM, de heer Nijpels.

'The first initiative for the NMP was taken in 1986 by the secretary of Health and Environment at that time, Mr. Nijpels.'

$Z e$ werden vergezeld door een kleine man, die voortdurend zijn armen over elkaar gekruist hield en naar de blauwe lucht keek.

'They were accompanied by a little man, who continuously held his arms crossed and looked at the blue sky.'

(12) De eerste tekenen van bewustzijn werden begeleid door een hevige pijn.

'The first signs of consciousness were accompanied by a sharp pain.'

The point is, of course, that the agent-phrases in (10) through (12) are emphasized (receive attention) as new information. So it appears that the notions of emphasis and attention as such are not sufficiently informative (not specific enough, to say the least) to be of much help in explaining what is specifically going on in the passive, ${ }^{12}$ and this situation easily leads to confusion on the part of students in writing courses.

Finally, but most importantly, the analyses mentioned do not distinguish between non-perfect and perfect passives, i.e. between worden- and $z i j n$-passives. But teachers of writing courses generally find that students have little or no problems in using the perfect passive; the passives that create the impression of "passivitis" are typically the non-perfect wordenpassives.

Consider first fragment (13), which is taken from the corpus of government language studied by Renkema (1981):

(13) De financiering van de nieuwe activiteiten zal moeten geschieden uit de $R$-en-D-begroting van het tot energiefonds om te vormen SNRfonds. Voor wat betreft de personeelsbezetting merk ik op dat de aangegeven mankracht niet geheel binnen de huidige formatie gevonden zal kunnen worden. Er wordt van uitgegaan, dat in 1976 door het RCN 13 manjaren kunnen worden vrijgemaakt door temporiseren of stopzetten van projecten waarop geen verplichtingen rusten. De resterende vacatures betreffen 3 academici, met disciplines die niet binnen het RCN kunnen worden gevonden i.c. economie, bedrijfskunde en geautomatiseerde documentatie.

'Financing of the new activities will have to take place within the R-and-D budget of the SNR fund, which is to be transformed into an energy fund. As for the personnel, I note that the indicated man-power cannot be found entirely within the present staffing. It is assumed that in 197613 full time positions can be made available by the RCN, by means of delaying or terminating projects for which no commitments exist. The remaining vacancies concern 
three academics, with fields that cannot be found within the RCN: general and business economics, and automated documentation.'

Here we have four cases of worden-passives, which definitely contribute to the overall "officialese" character of this text. Here the readability of the text can be greatly improved by changing a number of passives, for example as in (13)':

(13)' De financiering van de nieuwe activiteiten zal moeten plaatsvinden binnen het kader van de R-en-D-begroting van het tot energiefonds om te vormen SNR-fonds. Dit zal bepaalde gevolgen hebben voor de personeelsbezetting, want de voor de nieuwe activiteiten benodigde deskundigheid kan niet volledig gevonden worden binnen de huidige formatie. Het laat zich aanzien dat in 1976 het RCN 13 manjaren kan vrijmaken door bepaalde projecten te temporiseren of stop te zetten, waarop geen verplichtingen rusten. Dan zullen er nog voor 3 functies vacatures resteren, $n l$. voor academische disciplines die thans niet binnen het $R C N$ vertegenwoordigd zijn: economie, bedrijfskunde en geautomatiseerde documentatie.

'Financing of the new activities will have to take place within the R-and-D budget of the SNR fund, which is to be transformed into an energy fund. This will have certain consequences for personnel, since the expertise required for the new activities cannot be found completely within the present staffing. It seems plausible that in 1976, the RCN will be able to make 13 full time positions available by delaying or terminating projects for which no commitments exist. In that case there will remain three vacancies, viz. for functions in academic fields which are not represented within the RCN at present: general and industrial economics, and automated documentation.'

This reformulation contains a number of different alternatives for the passives in (13); I will return to the motivation for the differences later, but for the moment it suffices to notice that a fragment like (14) is very different: this contains a number of zijn-passives, and a reader's general impression from this text is not that it involves excessive use of the passive.

(14) Een belangrijke aanzet daartoe is gegeven in de interimnota Inkomensbeleid. Daarbij is tevens een wettelijke regeling inzake de vermogensaanwasdeling aangekondigd.

op het gebied van de kwaliteit van de arbeidsomstandigheden is eveneens nieuw beleid ontwikkeld, met name op het gebied van wetgeving (arbeidswet, veiligheidswet), gericht op verbetering van veiligheid en gezondheid van werknemers in hun werkomgeving. Dit 
aspect zal in de komende jaren bijzondere aandacht van de ondernemingen en van de overheid vragen.

'An important step is taken in the interim report on Income Policy. In that connection a legal settlement has also been announced concerning [workers'] sharing in the growth of capital.

With respect to the quality of the working conditions, new policies have been developed as well, in particular in the area of legislation (labor law, safety law), directed at improving safety and health of employees in their labor environment. In the years ahead, this aspect will require special attention from industry and from the administration.'

In fact, the active counterparts of the passives in (14) are not appropriate - at all. ${ }^{13}$ And less inappropriate non-passive formulations like is te vinden or is aanwezig "is present" in the first sentence hardly make any stylistic difference. ${ }^{14}$ Also, as mentioned before, teachers in composition courses consistently find that students have more trouble with the worden-passive than with the zijn-passive. But the characterization of the passive in terms of de-emphasizing the agent is not helpful in explaining this difference and thus does not provide a basis for an improvement strategy: it simply applies equally to the worden- and to the zijn-passive.

\section{The role of the passive auxiliaries}

\subsection{The hypothesis}

Let us now turn to an alternative approach. My claim will be that all passive sentences are more or less stative, but zijn-passives more so than worden-passives, and that part of the problem novice writers and government officials have with the passive is that the form they choose is sometimes not stative enough, rather than not sufficiently active. This difference can be associated with the semantic difference between the different elements involved (worden vs. zijn), i.e. with the "analyzability" of the passives.

First, both passives contain a past participle, which means that both involve the mentioning of a state: the end-state, or resultant state, of some process (the participle indicates an "a-temporal relation"; cf. Langacker (1982: 58-65; 1991: 5.2.1) and for Dutch, Pardoen (in press). Second, they differ in that the auxiliary in one case (worden) as such means "become", "enter into a state", and in the other case (zijn) "be", "exist". Finally, both present a situation in such a way that an agent is 


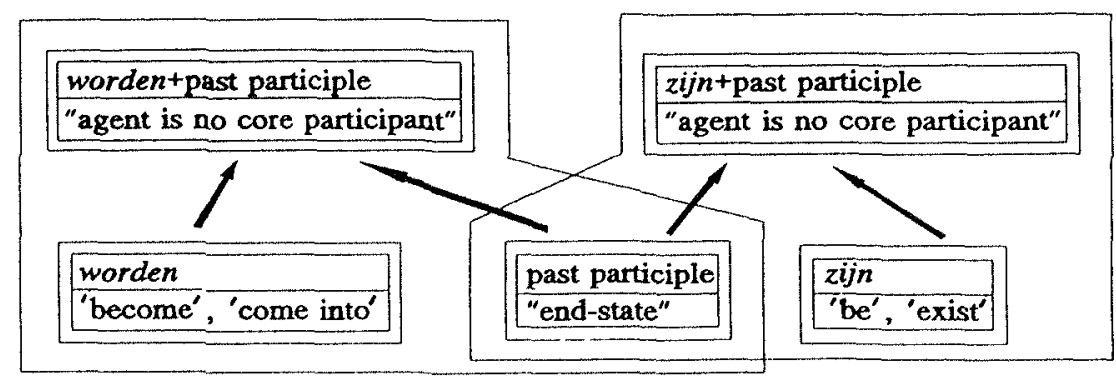

Figure 1. Schemas for worden- and zijn-passives

not a core participant in the situation. We can represent the elements and the relations between them schematically as in Figure 1.

Each of the elements worden, zijn, and the past participle contributes to the meaning of the complex schemas for both the worden-passive and the zijn-passive (this is indicated by the upward arrows); the aspect of an agent not being foregrounded is evoked by a combination of these elements, which is therefore a (complex) element in its own right. In other words: the elements out of which passive constructions are formed contribute their meaning to the meaning of the passive, but do not fully exhaust it; there is an aspect of meaning that is associated directly with the combination. ${ }^{15}$ The contents of the passive constructions are therefore neither completely reducible to the meanings of the elements combined, nor arbitrary (with respect to the meanings of those elements); as periphrastic constructions they constitute complex categories (hence the polygons containing both the schemas for the combinations and those for the elements), both formally and semantically. The semantic aspect of the combination corresponds to the traditionally recognized function of the passive: to present a situation not from the agent's perspective, often because the agent is completely backgrounded (and therefore not mentioned at all), but sometimes, as in (10)-(12), in order to make it possible to introduce the agent as the "point", the "news" of the sentence. It is this fact of the "grammaticization" of the combination of worden and a participle that differentiates this passive in particular from other combinations of verbs and past participles: it always implies that the producer of the resultant state described by the participle is external. Consider the differences between (15a) through (15c):

\section{a. We werden ingesloten (door onze tegenstanders) We be(came) surrounded (by our opponents) 'We were being surrounded (by our opponents)'}



b. We raakten ingesloten
We became surrounded
'We were getting shut in'
c. We waren ingesloten
We were surrounded
'We were/had been surrounded'

The difference between (15a) and (15b) is that in the first case there definitely is an external producer of the enclosure (though he need not be mentioned), while in the second there need not be one: it states no more than that "we" enter a state of being surrounded; the sentence may suggest that this situation arises because of our own stupidity, for example

- because of our entering a completely unknown canyon. Thus the difference is that the combination of worden and a past participle indicates the "coming into existence" of a state as produced by an external producer, while the combination of raken and a past participle only indicates "coming into existence". Note that the combination of waren with a past participle in (15c) in principle allows for both interpretations; we will return to this issue later.

In terms of the uses of the verbs worden and raken, we could say that worden has both a inchoative and a passive use, while raken is only used inchoatively. But the idea of "change" is present in both uses of worden, and this is precisely what differentiates worden-passives from zijn-passives, as I will now argue.

My claim will be that the past participle as well as the auxiliaries contribute to the conceptualization of a situation as not (prototypically) transitive in the sense of Hopper and Thompson (1980), i.e. all passives are mechanisms of detransitivization. But worden, explicitly indicating change ${ }^{16}$ ("coming into existence"), constitutes a less strong detransitivizer than zijn, simply indicating the existence of a state.

This is the central hypothesis of this paper. We will now first review some more evidence for it, especially for the idea of analyzability in this analysis, and then go on to argue that the special character of wordenpassives implied by it in fact provides a crucial step towards solving the problems noticed previously: why is it that worden-passives in particular give rise to problems of usage in texts?

\subsection{Worden and stative verbs of being}

One kind of evidence for analyzability of passives as well as for a special status of worden-passives involves the fact that past participles do not only combine with worden and zijn but also with a number of other verbs 
(such combinations are sometimes labelled "semi-passive"). An example of such a verb is staan 'to stand'. This can be used to mean 'it says', 'it is written' (e.g., De titel stond niet op de voorpagina, lit.: 'The title did not stand on the front page'; 'The title wasn't written/printed on the front page'). As such it can be combined with the past participles of a limited number of semantically related verbs (ANS 1984: 528), such as aangekondigd 'announced', vermeld 'mentioned', beschreven 'described'. The verb staan does not lose its meaning in such combinations, but rather contributes its specific import ("to be in some vertically oriented position"), more concrete than the very schematic zijn 'to be', to the sentences in which it is used. A number of other verbs (liggen 'to lie', 'to be stretched out', zitten 'to sit/be seated', blijven 'to stay', 'to remain') display a similar behavior; here are some examples of such combinations:

(16) aangekondigd staan, lit. 'to stand announced'; 'to be announced' vermeld staan, lit. 'to stand mentioned'; 'to be mentioned' uitgestald liggen, lit. 'to lie displayed'; 'to lie on display', 'to be displayed'

begraven liggen, 'to lie buried'

beklemd zitten, lit 'to sit stuck'; 'to be stuck'

opgescheept zitten met iets, lit. 'to sit landed with something'; "to

be landed with something'

gehandhaafd blijven, lit. 'to remain maintained'; 'to remain in

force'

gespaard blijven, lit. 'to remain spared'; 'to be spared/preserved'.

The verbs staan, liggen, zitten, blijven ('to stand', 'to lie', 'to sit', 'to remain', respectively) are all semantic cognates of $z i j n$ ('to be'); they all indicate specific "modes of being" ("be in a particular position", "continue to be"), whereas zijn itself is the most schematic verb of all. And the semantics of all of these types of combinations is indeed very similar to that of the zijn-passives: they indicate specific ways in which a resultant state exists. Thus, we may represent the relations between these elements (in the same format as in Figure 1) in Figure 2.

We see then that Figure 1 involves elements of a more schematic nature than Figure 2, but that the nature of the combination is essentially the same. In fact, all forms of the passive in Dutch involve reference to existence of a state: worden 'coming into existence' is conceptually related to zijn 'existing' as a kind of inchoative. We can therefore give the most abstract representation, generalizing over all combinations of existencerelated verbs with past participles treated so far, in Figure 3.

Figure 3 in effect presents a (grammatical) rule of Dutch; note that it has the same structure as the more concrete representations in Figures 1 


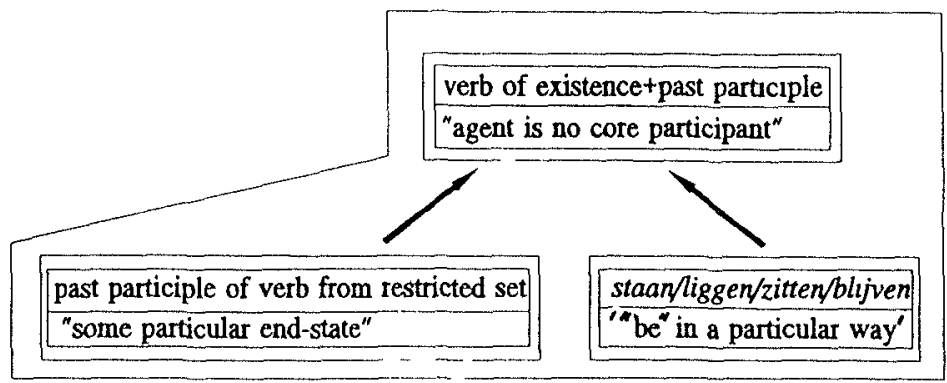

Figure 2. Schema for "seml-passives"

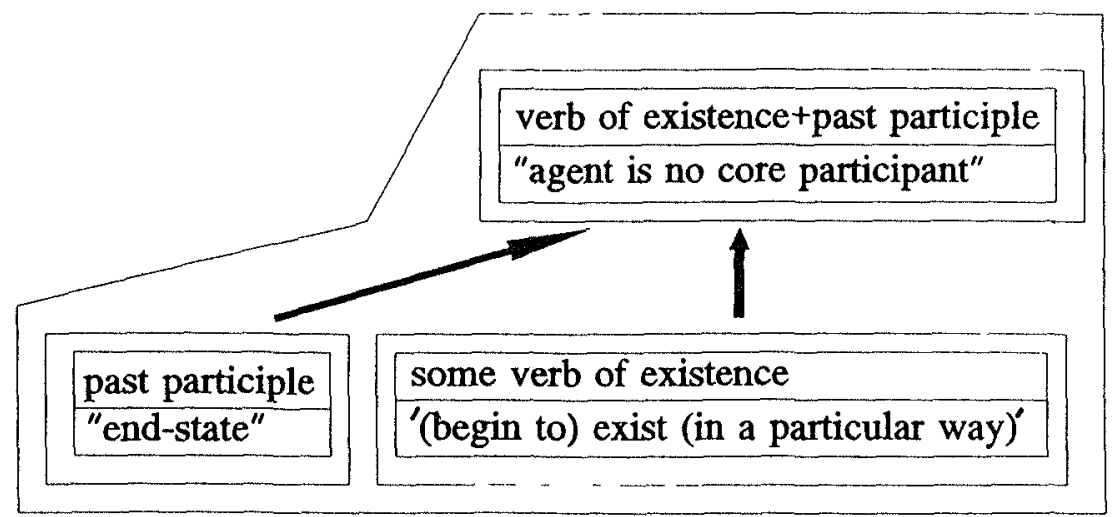

Figure 3 Generalized schema for passives in Dutch

and 2. The combinations listed under (16) are direct instantiations of the general structure in Figure 3, although the latter is not to be conceived of as a generative rule, but rather as a "conventional structure available for ... categorization" (Langacker 1990: 8). Not all combinations of existence-related verbs with past participles of any kind do in fact occur: low-level generalizations as embodied in Figure 2 have to be included in the grammar as well. The rule represented in Figure 3 is just a very abstract schematization of such lower-level rules, without there being a qualitative difference between them (cf. Langacker 1988 and 1990 for general discussion of a model of grammatical description incorporating such assumptions). So a comprehensive account of passives in Dutch effectively consists of a network of related schemas, of different levels of generality and abstraction. ${ }^{17}$

This approach has a number of advantages. The more abstract schematization, for example, naturally expresses the fact that the specific combinations of staan, etc. with past participles differ from the worden-passives 
in the same way as the zijn-passives do, the former involving some idea of 'change', the latter just indicating state. Note furthermore, that the difference between these 'semi-passives' and worden-passives cannot be based on a difference of tense, which confirms that tense is not sufficient, and perhaps not even fundamental, in characterizing zijn-passives either (cf. section 2); it is clear, though, why the use of zijn has been associated by grammarians with the perfect tense, and the use of worden with the non-perfect tenses: a zijn-passive most schematically designates the existence of a state when a change of state as designated by a worden-passive has been completed. This situation is not at all unusual crosslinguistically; consider the following quotation from Nedjalkov and Jaxontov (1988: 45):

As regards the resultative and passive of transitive verbs, they are frequently combined, the passive form being used to express the resultative meaning (in grammars, the latter case is usually called statal passive ... and is opposed to actional passive ...). Moreover, not infrequently, if they are not combined and differ formally, the resultative and passive "compete" with one another in the sense that they can be interchangeable in certain contexts, the differences in the overall meaning being insignificant. This is particularly frequent in the case where the passive occurs in the perfect, as the perfect form of the passive usually implies the present tense of the resultative... .

Thus Nedjalkov and Jaxontov equate the notions of statal passive and resultative for the many languages that have no separate forms for passive and resultative, and they go on to note that the difference between these two, even in languages having separate forms, is relatively insignificant in the perfect, since the present perfect of the passive is usually equivalent to the present of the resultative. This applies quite directly to the situation . in Dutch: the combination of zijn and past participle indicates the existence of a resultant state. The interpretation as present or past perfect passive on the one hand, and as simple present or past stative ("resultative") on the other, are partly, perhaps even largely, overlapping "shades" of the same phenomenon: the same two elements being combined in the same way. ${ }^{18}$ In contrast, the worden-passive, generally referring to a change, is, unlike the zijn-passive, not so readily associated with a purely stative situation: it is less of a detransitivizing device than the zijn-passive.

At the same time, the specification of particular combinations of past participles with verbs like staan differentiates these from those with both worden and zijn. In the case of the former, one has to know those specific combinations as such, with their specific "value". It is not impossible to create novel combinations according to the general schema, but these are recognized as such by the speakers of the language and they require 
specific contexts in order for their specific use to be determined. But there is no need for such concrete specification in the case of worden- and zijnpassives: the generality indicated in Figure 1 is adequate, in the sense that these verbs can be combined with a past participle from a vast range of verbs, to form a standard expression of the language. The only condition is that the meanings of the elements involved and their combination can lead to some consistent interpretation. It is therefore not surprising that the specific combinations have a much more restricted use, both qualitatively (as indicated above) and quantitatively: for example, the entire Eindhoven Corpus of over 53,000 sentences contains only 6 instances of staan + past participle, against more than 2,000 instances of worden-passives. In the remainder of this paper, we will concentrate on the analysis of this type of passive.

Note that this entire account implies that the Dutch passives must indeed be viewed as analyzable, in the sense which Langacker (1982) proposed for the passive in English (see also Langacker 1991: 5.2.1): the different elements making up a passive construction can be seen as each contributing to the interpretation of the entire sentence, being used in a way that is related to their other uses, even if their contribution does not completely exhaust the interpretation of the sentence. The traditional view sees the worden-passive as an unanalyzable unit, ${ }^{19}$ diachronically derived from a combination of the copula worden, but no longer related to it synchronically. Instead, I claim that a crucial part of what the worden-passive indicates is the coming into existence of the state indicated by the participle; in other words, the use of worden as a passive auxiliary is intimately related to its other use as a copula (for which the literal translation 'to become' is fully adequate): both involve an idea of 'change of state'. As for the zijn-passive, it indicates the existence of the state designated by the participle. Again, it is understandable in this view that zijn 'to be' is used here, given that it is generally used to indicate the existence of states.

So all forms of the passive in Dutch involving a past participle crucially involve the notion of a state (cf. also Langacker 1982: 61-62 on the stativity of the past participle); furthermore, we have already seen that the auxiliaries involve reference to a state, too: worden is inchoative with respect to zijn. At the same time, worden is unique in the system: it differs from all other passive 'auxiliaries' in that it designates change. ${ }^{20}$

\subsection{Worden and deliberate backgrounding}

The special status of worden in this analysis also allows for a step towards solving the problems noticed previously: why is it that worden-passives 
in particular give rise to problems of usage in texts? The analysis makes it explicit that only worden designates a change of state, whereas zijn simply designates the existence of a state (as do the "be-like" verbs staan, etc.). The use of worden evokes the concept designated by the verbal stem of the participle as a process.

It is something special to present the occurrence of a process from a perspective other than that of the entity bringing it about, at that very moment: the agent is there, but it is not selected as the point of view for the presentation of the situation; this is the case with the use of a wordenpassive.

It is far less special to present the existence of a state from a perspective other than that of the entity which, in a different situation previous to the one designated by the sentence, brought it about; this is the case with the zijn-passives.

The worden-passive, implying the presence of an agent but not selecting it as point of view, therefore tends to be interpreted as deliberate backgrounding of an agent far more easily than the zijn-passive, not implying the presence of an agent (see section 5.2.2 for a qualification of this statement); in zijn-passives, the idea of a specific agent who must (or may) have performed some activity in order to produce the state designated by the participle is generally not evoked at all, so that people often even hesitate to categorize them as "passive", in the prototypical sense of "action not presented from the agent's perspective". Consider sentences (17) through (21), extracted from the Eindhoven Corpus:

(17) Het puin was geruimd en in de fundamenten tekende zich het plan van de verdwenen woning af.

'The debris was (had been) cleared away and the foundations showed the plan of the vanished home.'

(18) Het huis was op 16 april 1941 door een bom getroffen, maar sindsdien weer redelijk opgeknapt, al zag het er nog wat sjofel uit.

'The house was (had been) hit by a bomb on April 16, 1941, but since then [it was (had been)] fixed up rather well, though it still looked somewhat shabby.'

(19) Haar hoed was met glanzend lint onder de kin vastgeknoopt. 'Her hat was (had been) tied under her chin with a glossy ribbon.'

(20) Het boek is dus niet bedoeld als naslagwerk.

'So the book is (has) not (been) intended as a reference work.'

(21) Het beeld was uit fokus, verschoven, achterhaald.

'The image was out of focus, shifted, obsolete.' 
The question is: are the non-italicized phrases instances of passive (in the [present or past] perfect tense), or do they constitute statives (in the simple [present or past] tense)? I want to suggest that in many cases this question, frequently a stumbling block for students as well as for professional linguists, ${ }^{21}$ does not make much sense. In each case above, the fact that the states indicated are the result of certain actions by certain agents is not very important at all. What matters is the existence of the states, i.e. that which is directly indicated by the combination of zijn 'to be' and the past participle. The debris being gone, the plan of the home becomes visible (17); three conditions are being compared in (18): having been hit by a bomb, having been fixed up, and still looking somewhat shabby, and so on.

What is particularly striking in all these examples and many like them is that the idea of a particular agent being backgrounded is not evoked at all, in contrast to the situation with the analogous worden-passives. For example, it is true that (19) implies that there has been an action of tying, hence an agent. But the focus is so much on the condition of the hat and the ribbon that the relation of this agent to the situation (and presumably also to the story, at this point) is not an issue at all; it might have been anybody, including the possessor of the hat herself. But in the parallel worden-passive, this latter interpretation is hardly possible: instead, that formulation so strongly suggests the backgrounding of an agent that it is virtually obligatory to assume someone other than the possessor herself as doing the tying. As indicated before, because of the possibility of the reference to change, the worden-passive more than the zijn-passive tends to be interpreted as deliberate backgrounding of the agent (for the qualifications in this statement, I again refer to section 5.2.2).

The relations schematized in Figure 1 also extend to combinations of worden or zijn and past participles of verbs taking only one argument, in sentences with initial er ('there', unaccented). The semantics of these socalled pseudo-passive sentences exhibits a number of particular features, notably that the (implied) agent is almost obligatorily interpreted as animate - a condition that does not hold, at least not to the same degree, in other, "ordinary" passives (cf. Kirsner 1976a, 1983, for discussion). The difference between worden-pseudo-passives and zijn-pseudo-passives may sometimes be sufficiently characterized as the difference between present and perfect, but it often (also) involves a process vs. state interpretation, with the former being used to suggest deliberate backgrounding of the agent. The following examples again come from the Eindhoven Corpus: 
(22) $\mathrm{Er}$ wordt There be(comes) run and rolled and somebody calls: ... 'There is running and rolling and somebody calls: ...'

(23) Er wordt links en rechts als een waanzinnige geopend There be(comes) left and right like a madman opened 'Right and left, frenzied openings [of art exhibitions] take place'

These examples and others like them have an ironic flavor; the use of worden implies the occurrence of a process, hence the presence on the scene of the actors of the running, rolling, and opening, but the sentences present the processes as if they originate from no specific source. No such conflict, thus no such irony, is present in any of the (five) zijn-pseudopassives in the Eindhoven Corpus; two typical examples are:

(24) Er is jarenlang verbazend hard gewerkt There is years-long amazingly hard worked 'For years, there has been some amazingly hard working'

$\mathrm{Er} \quad$ is buitenom geschilderd en binnen moet het ook nog There is around painted and inside must it also still 'The exterior is (has been) painted and the interior is due, too'

Sentence (24) designates a situation of "amazingly hard working" that has been continuing "for years", and (25) designates the resultant state of being painted of the exterior of some farm (specified in the context).

We see then that zijn-passives, including "pseudo"-passives, present a situation the producer of which need no longer be present; they therefore generally do not give rise to an interpretation of deliberate backgrounding of the agent. On the other hand, worden-passives in general (i.e., both "ordinary" and "pseudo"-passives) present an ongoing process; they thus imply the presence of an agent without making this participant into the entity from whose perspective the situation is presented, and therefore may give rise to an interpretation of deliberate backgrounding of the agent.

It is precisely this property of the worden-passive that is often involved in stylistically infelicitous effects of passives. Recall fragment (13) above; it contains the following passive:

(13) a. Er wordt van uitgegaan

There be(comes) from assumed

'It is assumed' 
The problem here is that the sentence rather emphatically evokes the idea of a backgrounded agent, as if the author has something to hide. And we also have:

b. dat in 1976 door het RCN 13 manjaren that in 1976 by the RCN 13 full time positions kunnen worden vrijgemaakt can be(come) freed 'that in 197613 full time positions can be made available by the RCN'

The problem here is that on the one hand the passive suggests that the idea of the agent is not activated, not thematically central in the text at this point; but on the other hand the word order, with the agent at the beginning of the clause, suggests that it is. This is a kind of passive sentence that can easily and often profitably be turned into an active one. What this comes down to is that so-called perfect passives in Dutch are often not fully passive, in the sense of "action not presented from the agent's perspective". The fact that they refer to the existence of a (resultant) state rather than to its coming into existence means that the notions of action and hence also of agent are not readily associated with the zijn"passive"; they are associated, however, with the worden-passive.

\section{Passive and other detransitivizing devices}

\subsection{Degrees of transitivity}

The analysis so far holds that worden-passives, referring to change, are a less strong detransitivizing device than zijn-passives, which are often (though not necessarily always) indistinguishable from stative resultatives. Thus, situations designated by zijn-passives are closer to prototypical stative situations than those designated by worden-passives. But neither do worden-passives designate prototypical transitive situations, of course; in terms of a scale of transitivity, ranging from fully transitive (exemplified by prototypical transitive sentences in the sense of Hopper and Thompson 1980) to fully stative, worden-passives take a kind of middle position, while zijn-passives are relatively closer to the stative end of the scale.

This suggests a particular diagnosis of the problems of novice writers and government officials, rather different from that generally given in composition textbooks: if the zijn-passive is the more stative one, and if the problems concern mainly the worden-passive, then the nature of this problem might frequently be that writers rightly feel that a more or less 
stative presentation is called for but do not pick out the optimal way of doing that. Of course, in some situations the problem may very well be that the formulation is not transitive enough (i.e. in case the agent should be in the foreground), but the possibility that it is not sufficiently intransitive should at least be taken as seriously. ${ }^{22}$

What I suggest is that stylistically infelicitous use of passives should often not be solved by transformation into non-passive counterparts (i.e. sentences with higher transitivity); rather, the remedy should consist in choosing a lower degree of transitivity than is expressed by a wordenpassive. Thus, the idea is that the scalar conception of transitivity, fundamental to recent research in functional and cognitive linguistics (cf. Hopper and Thompson 1980 and Rice 1987, among others), can actually be put to practical use. So let us now have a look at some detransitivizing devices that need not exhibit the disadvantages of worden-passives.

\subsection{Possible non-passive detransitivizing devices}

\subsubsection{Fronting}

Part of the prototype of a transitive event is that its elements are organized in a particular order, starting with the starting point of the activity: its source, or agent. Prototypical transitive sentences exhibit that order linearly. In terms of Langacker (1991: 7.1.3.), the conceived "natural path" of energy flow (from energy source to energy sink) corresponds with another "natural path", that of the order of the words. It follows that sentences not starting with the energy source are not prototypically transitive; i.e. fronting sentences are expected to exhibit reduced transitivity.

In fact, Onrust (1988) has suggested that in Dutch, fronting (in particular object-fronting) may be viewed as, among other things, a detransitivizing device. Consider the examples in (26) and (27) (for ease of presentation the boundary between the first and the second element is indicated by "/").

(26) Met een dergelijke maatregel / zet de minister een eerste stap op een gevaarlijke weg.

"With such a measure / the minister takes a first step on a dangerous road"

(27) De klerenkasten / heb ik helemaal uitgepakt. Zijde, fluweel en bont / wierp ik op een hoop... . Vijfentwintig paar schoenen / bekeek ik aandachtig, een voor een. (Hermans 1951:41)

'The clothes closets / I stripped completely. Silk, velvet and fur / I 
threw on a heap. ... Twenty-five pairs of shoes / I viewed carefully, one by one.'

In (26), a sentence from a newspaper article, an instrumental phrase has been fronted and in (27) we have fronted objects in a number of sentences. In such cases, the deviation from the transitive prototype is that the starting point of the sentence does not coincide with the starting point (the source) of the activity. What evidence can we adduce for the claim that this actually involves reduction of transitivity?

Note that a sentence like (26) uses the description of an action to characterize the measure involved as "a first step on a dangerous road". The reduced transitivity of such a characterization emerges most clearly when one conceives of the most natural function of a sentence like this in coherent discourse: it is very much suited to function as, for example, the topic-sentence of a paragraph (cf. Onrust in prep.), or as a conclusion to an exposition of an argument. In particular, one does not tell "the plain facts" of a line of events completely in sentences like these, indicating that they are indeed reduced in transitivity, in the sense of Hopper and Thompson (1980).

Note that in the prototypical order, it is not so clear what kind of discourse function the sentence would most naturally serve:

De minister zet met een dergelijke maatregel een eerste

The minister puts with a such-like measure a first

stap op een gevaarlijke weg

step on a dangerous road

'The minister takes a first step on a dangerous road with such a measure'

$(26)^{\prime}$ is less suggestive about such a specific function than (26); having an "unmarked" order, this sentence fits into a wider range of contexts, i.e. is more "vague" as to a particular kind of context.

In the object-fronting cases in (27), we have the context available. They are taken from a novella by the eminent Dutch writer Willem Frederik Hermans. Consider the context:

(27)' Toen ik er nog wat langer had gewoond, verliet ik het huis bijna niet meer... . Ik had behoefte aan geen enkele bezigheid. Meestal was ik op de slaapkamer. ... Elke dag bleef ik in het bad liggen. ... Dan liep ik op en neer, voorwerpen betastend, zonder ze te onderzoeken. Op medicijnflesjes en poederdoosjes, op zakdoeken en aan de randen van lakens waren namen geschreven die ik niet probeerde uit te spreken. De klerenkasten heb ik helemaal uitgepakt. ... Zijde, fluweel en bont 
wierp ik op een hoop. ... Vijfentwintig paar schoenen bekeek ik aandachtig, een voor een. Want schoenen zijn het enige dat iets van een mens bewaart als hij afwezig is. ... (Hermans 1951: 40-41)

"After I had lived there somewhat longer, I hardly ever left the house. ... I felt no need for any occupation whatsoever. Most of the time I was in the bedroom. ... Every day I stayed in the bath....Then I walked up and down, touching objects, without examining them. On medicine bottles and powder boxes, on handkerchiefs and on the border of sheets, names were written which I did not try to pronounce. The clothes closets I stripped completely. Silk, velvet and fur I threw on a heap. ... Twenty-five pairs of shoes I viewed carefully, one by one. For shoes are the only things that retain something of a person when he is absent.'

This paragraph does not describe a series of unique events but rather elements of a ritual that is repeated for an unspecified number of days: the protagonist simply continues living in this house which is not his. So we have a static characterization of the situation during the time that the protagonist has the house to himself. The fronting sentences contribute to this overall character of this portion of the text: they present elements of the situation, in the initial phrases, and then go on to comment on these.

These effects are very similar to what Prince $(1981 ; 255-256)$ has shown for topicalization sentences in English. ${ }^{23}$ They have, as she calls it, "the flavor of a list" (1981: 255). She gives the following example (Prince 1981: ex. 26):

(28) a. I used to live in Philadelphia and I often went to Atlantic City (28) b. Philadelphia I used to live in and Atlantic City I often went to

Prince comments on these sentences as follows:

In [(28a)], it is easy ... to understand the first clause, I used to live in Philadelphia, as the setting for the whole sentence, i.e. while living in Philadclphia, the speaker often went to Atlantic City. This understanding does not seem to be available for [(28b)]; rather, we find a symmetric coordination, a listing of the speaker's relation to two (Eastern) cities. (Prince 1981: 255--256)

So while it is at least possible to read the second clause of (28a) as reporting an activity, and thus presenting the next step in a sequence of events, such a reading is virtually excluded in (28b). The latter sentences rather serve to characterize the two cities (in terms of the speaker's relation to them). These characterizations are understood as contributing to the description of an all-encompassing topic; they do not narrate 
events on the (main) story line (which is not, of course, to say that they are less important for understanding the text).

So let us assume that fronting is indeed a detransitivizing device. In fact, prototypical passives (excluding impersonal ones) and prototypical object fronting sentences have highly parallel orderings: both are about what happens to a patient. ${ }^{24}$ But fronting does not have the effect of deliberate backgrounding of the agent; in (27)', for example, the " $I$ " is still there and clearly contributes greatly to the cohesion of the passage in itself and to the cohesion of this passage with the entire story. This is an important difference, which can, in specific circumstances, make fronting a potentially good alternative to passive, viz. precisely when part of the motivation for the use of the passive involves the fronting of the patient. At the end of the next section we will discuss some evidence relating to this suggestion.

\subsubsection{Modality, predicate nominals and the perfect}

One of Hopper and Thompson's (1980) transitivity parameters is modality. Including a marker of modality in a sentence reduces its transitivity, because the sentence no longer "just" relates a fact, but considers it a possibility, etc.; foregrounded events (on a "story line") are not reported by modal sentences. Rather, their primary use may be seen as commenting on their topics. Examples are (29) and (30).

(29) Hij zal twee artikelen schrijven

He will two papers write

'He will write two papers'

Die wetenschap blijkt al oud te zijn

That knowledge appears already old to be

'That knowledge proves to be very old already'

Such sentences are never fully transitive. Sentence (29) does not relate the occurrence of an event, but predicts it, clearly an assessment by the speaker. (30) ascribes some property to its subject as "apparent", another explicit indication of a speaker's assessment of the situation, and also one that does not make the sentence as a whole more similar to a prototypical action.

As another example of a strong indicator of low transitivity, consider predicate nominal constructions like the one in (31):

(31) De dollar is nu erg duur

The dollar is now very expensive

'The dollar is very expensive now' 
Such copular constructions simply and explicitly predicate a property of their subjects and thus are explicitly very low in transitivity. Sentences with modal auxiliaries and/or with copular verbs are therefore also possible candidates for non-passive, low-transitivity sentences, i.e. sentences not presenting an action, and therefore no agent either, let alone one that is deliberately backgrounded.

Another construction that is well known for its lowering of transitivity is the perfect. Thus, Hopper and Thompson (1980: 293) call the perfect "a low-Transitivity tense"; earlier, Langacker and Munro (1975: 825) observed that a sentence in the perfect tense "makes an assertion of existence - the existence of an accomplished or realized state resulting from an earlier event" (cf. also Beedham 1982: 89 and the references cited there). ${ }^{25}$ The reason for this should be clear: the perfect evokes the idea of a resultant state, designated by the past participle. Sentences like (32) and (33) do not focus on the course of events but on what comes after certain events, "using" these events as parts of characterizations of the referents of the subjects at the time of the utterance:

Hij heeft vorig jaar twee artikelen geschreven

He has last yeartwo papers written 'He has written two papers last year'

Jan is er met een grote boog omheen gelopen John is there in a big curve around walked 'John has skirted round it in a wide circle'

It is therefore no surprise that a number of authors have noted strong similarities between the perfect and the passive (Langacker and Munro 1975: 824-827; Beedham 1982: 91; for a somewhat idiosyncratic account, cf. Comrie 1981). In the perspective of Hopper and Thompson's theory of transitivity, even a more specific point of view should be taken: the passive and the perfect are both detransitivizing devices; the combination of the passive with the perfect in one clause should therefore provide a stronger reduction of the transitivity of the clause than the use of the passive alone. This accords completely with our previous conclusion that in Dutch, perfect passives are stronger detransitivizers than non-perfect ones; in a sense, it provides the motivation for the use of the auxiliaries in the respective passives: $z i j n+$ past participle, designating the existence of a state, for the lowest degree of transitivity (i.e., the perfect), and worden, indicating change of state, for a "less lower" degree (i.e., nonperfect).

This way of reasoning provides us with an important cue for a way in 
which the idea that worden-passives exhibit, so to speak, "middle" transitivity must be qualified. For if the reasoning is correct, we expect a combination of worden-passive with other indications of lower transitivity to also provide stronger detransitivization than worden on its own. Recall that we said that the presentation of the occurrence of a process from a perspective other than that of the agent evokes the idea of more or less deliberate backgrounding of that agent; but a process need not always be presented as occurring, and we then expect the idea of the agent's backgrounding also to be less relevant in worden-passives. This is precisely what we need in order to describe the use of cases like (34):

[Dezegrond is veel te sterk vervuild;] [This soil is much too strongly contaminated;] er kan zeker vijftig jaar lang niet gebouwd worden. there can certainly fifty year long not built be(come). [The soil here is contaminated far too badly;] the site definitely cannot be built upon for at least fifty years.'

The second of these two clauses is a worden-passive, but an important difference from other worden-passives considered so far is that this one does not at all suggest deliberate backgrounding of an agent; in fact, the idea of a specific agent is not evoked at all by this clause. The dominant question clearly concerns the quality of the soil: is it suited for building? Now note that this clause contains a number of detransitivizing devices:

- no mention of an individuated object (no particular buildings are mentioned; cf. Hopper and Thompson's (1980: 252-253) parameter "O non-individuated");

- a modal auxiliary: kan ('can', 'irrealis');

- a negation: niet ('not', 'negative');

- a durational adverbial: zeker vijftig jaar lang ('for at least fifty years'; 'non-punctual').

Precisely because the entire sentence is about the impossibility of the process of building, and "stretches" this condition over a period of at least fifty years, it does not evoke the suggestion of a specific agent. Thus, the use of the passive simply accords with the other detransitivizers, and is not to be criticized; on the contrary, it is used quite well here. Part of these observations constitutes a qualitative parallel to the quantitative finding of Hopper and Thompson (1980: 293): "a greater percentage of passives than actives in English have verbs in the perfect or past perfect, which are low-Transitivity tenses (26\%:19\%), and are found with modals, again a low-Transitivity property $(30 \%$ more)." When combined with 
perfect or modality, passive sentences are lower in transitivity, and such combinations strengthen the conceptual consistency of sentences and texts and thus their stylistic quality.

\subsection{Practical evidence}

Strong evidence in support of this analysis comes from the experience of its application in writing courses. ${ }^{26}$ First, it gives writers a far more detailed picture of what to look for when editing a draft; instead of the general warning "Watch your passives", it draws attention to particular features, such as the use or non-use of perfect marking, modality, negation, etc. Secondly, it provides a larger and more flexible set of alternatives than just "Use the active voice", to provide useful instruments in editing practices, helping writers to improve their command of the language much more than the traditional approach.

Other evidence is provided by an interesting experiment reported on in Cornelis (1990: 5.2.1). She asked ten subjects to try to revise a fragment of a text in which the passive was clearly over-used (to say the least). Subjects applied all kinds of strategies to improve the text, and a number of them retained the passive in several cases but added the future modal zullen. Several other revisions were in the same spirit. Readers indeed tend to find texts that are rewritten in this way to be more readable than the original versions (even though some of the texts are still not optimal).

The results from the same experiment showed that the future modal zullen was also often added in combination with fronting, and removal of the passive. ${ }^{27}$ This provides evidence in support of the idea of the previous section, viz. that fronting may at least constitute a partial alternative for a passive formulation, although participants in writing courses tend to find it more difficult to consciously use this instrument than to add indications of reduced transitivity like modal elements and perfect tense; part of the reason for this greater difficulty is probably the primary role of word order in the interpretation of the information structure of sentences and texts (roughly: the distribution of old and new information, and the connections between successive sentences): changing word order may threaten the connectedness of the sentences in the text. Nevertheless, at least in combination with modality, fronting is seen to lead to useful results in editing tasks.

Thus, we have given substance and support to the hypothesis formulated at the beginning of section 5: the problem with the passive in the prose of novice writers and government officials is sometimes precisely that the writer, composing an expository text and not a narrative, rightly uses an expression of reduced transitivity, but does not find the one that is best suited to that job when s/he uses a worden-passive. Such writers 
should then be advised to use more clearly stative expressions in such cases, rather than transforming their passive sentences into active ones. This is particularly useful, of course, when the use of the active voice is felt to be inappropriate or threatens the cohesion of the text. Recall the officialese fragment (8) and the revision suggested by Overduin (1986) in (9) (repeated here):

(8) Wanneer het voertuig wordt bestuurd door een minderjarige, wordt door de verzekeringsmaatschappij verplicht gesteld dat de polis wordt ondertekend door de ouder of toeziend voogd, waarbij aangenomen wordt dat de richtlijnen van formulier 3 onverkort nageleefd worden. 'When the vehicle is driven by a minor, it is required by the insurance company that the policy is signed by the parent or guardian, in which case it is assumed that the directives of form 3 are observed without any restriction.'

(9) Wanneer een minderjarige het voertuig bestuurt moet de ouder of toeziend voogd de polis ondertekenen. De verzekeringsmaatschappij verplicht hiertoe. Verder neemt de verzekeringsmaatschappij aan dat men de richtlijnen van formulier 3 onverkort naleeft.

'When a minor drives the vehicle the parent or guardian has to sign the policy. The insurance company requires this. In addition, the insurance company assumes that one observes the directives of form 3 without any restriction.'

- In view of the analysis presented here, a revision as suggested in (35) should be far more readable: in the first clause, the passive is replaced by a copular construction, in the second it is combined with a modal, and in the third we have again a simple copular construction. ${ }^{28}$ In fact, it is indeed far better, and generally felt to be a real improvement by participants in writing courses.

(35) Als de bestuurder van het voertuig minderjarig is, moet de polis ondertekend worden door één van de ouders of de toeziend voogd; in een dergelijk geval zijn de richtlijnen van formulier 3 onverkort van toepassing.

"If the driver of the vehicle is not of age, the policy must be signed by one of the parents or the guardian; in such a case the directives of form 3 are applicable without any restriction.'

Consider also the revision in (13)' again (with passives and substitutions for original passives in roman print):

$(13)^{\prime}$ De financiering van de nieuwe activiteiten zal moeten plaatsvinden binnen het kader van de $R$-en-D-begroting van het tot energiefonds 
om te vormen SNR-fonds. Dit zal bepaalde gevolgen hebben voor de personeelsbezetting, want de voor de nieuwe activiteiten benodigde deskundigheid kan niet volledig gevonden worden binnen de huidige formatie. Het laat zich aanzien dat het RCN 13 manjaren kan vrijmaken door bepaalde projecten te temporiseren of stop te zetten, waarop geen verplichtingen rusten. Dan zullen er nog voor 3 functies vacatures resteren, $n l$. voor academische disciplines die thans niet binnen het $R C N$ vertegenwoordigd zijn: economie, bedrijfskunde en geautomatiseerde documentatie.

'Financing of the new activities will have to take place within the R-and-D budget of the SNR-fund, which is to be transformed into an energy fund. This will have certain consequences for personnel, since the expertise required for the new activities cannot be found completely within the present staffing. It seems plausible that the $\mathrm{RCN}$ will be able to make 13 full time positions available by delaying or terminating projects for which no commitments exist. In that case there will remain 3 vacancies, viz. for functions in academic fields which are not represented within the RCN at present: general and industrial economics, and automated documentation.'

As discussed towards the end of section 4, the second and third of the original worden-passives were stylistically awkward because of the deliberate backgrounding of the agent through the passive. Removal of this backgrounding is the remedy in the third case, and construing the existence of plausibility (in a "middle" construction with the weak reflexive $z i c h$ ) instead of a process of assuming, does it in the second case. ${ }^{29}$ In the first case, there is no reason for removing the passive formulation; it is of the same type as (39): it states a negative possibility and does not . strongly suggest the presence of a "hidden" agent. The fourth case is also of this type; for reasons of variation, for example, one may choose to substitute something for the worden-passive, provided that the alternative formulation is not more transitive than the original one; this condition is fulfilled by the combination of zijn "to be" and past participle, i.e. a copular construction/statal passive/resultative/perfect passive (as discussed, the present approach, assuming analyzability of the construction, makes it unnecessary to assign the sentence to one of these "categories" an unavoidably arbitrary and artificial choice).

\section{Conclusions}

A general conclusion from this study is that practical approaches to problems of language use, like those encountered in composition, may 
benefit from deeper theoretical lingustic insight into the phenomena involved And the applicability of the analysis might very well extend beyond problems of composition, the teaching of English to Dutch speakers, or the teaching of Dutch to foreigners, might also benefit from it We observed at the end of section 2 that both in English and in Dutch the most simple, direct way of evoking the idea of a state (without connotations about some process bringing it about) was to use the auxiliary meaning "be" with a past participle The analysis of the Dutch "perfect passive" has subsequently shown this to be the prototypical use of that form Furthermore, it was shown that a particular parameter (degree of stativity/low transitivity, with specific factors like negation, modality, etc ) is involved in the interpretation of passives, this parameter 1s also relevant to the choice of progressive and/or perfect in English, and thus may be expected to provide a basis, also for pedagogic grammars, to go beyond such statements as that "the interpretation of $b e+$ participle largely depends on context and on the type of lexical verb involved" (Aarts and Wekker 1987 275)

Finally, this study shows that the cognitive/functional approach to language is particularly well suited to give rise to insights that can be related to practical problems such as these, as it can for other problems outside its own immediate domain, this result in fact provides strong empirical support for the approach as a whole, beyond that of "fitting the facts"

Recelved 9 January 1991

Revislon recelved 12 December 1991

University of Utrecht

\section{Notes}

* Most of the work for this paper was done while I was a visiting scholar at the Depart ments of Linguistics of the University of California, Santd Barbald, and of the Univer sity of Californid, San Diego in 1990 This work was supported by the Netherlands Organization for Scientific Research (NWO), grant S 30-317 I wish to thank the participants in the discussions following my presentations of preliminary veisions of this work for their contributions to my thinking In partıcular, I would like to thank Bob Kirsner, Ron Langacker, Theo Janssen Lachlan Mackenzie, Sandra Thompson, Louse Cornelis, Dirk Geeraerts, and two anonymous reviewers, for help, suggestions, and valuable comments on previous versions of this paper Naturally, all remaining eirors are my own This work was conducted within the framework of the Free University Amsterdam Research P1ogram "Functional Language Research Grammar and Pragmatks" (LETT/88-10)

1 This situation also deprived other fields working with language of the possibility of being informed by theoretical linguistic considerations, and I believe this has had some 
negative effects on these other fields as well Linguists are famliar with the situation of people in other disciplines such as psychology and philosophy, and in applied fields like language teaching, doing "amateur linguisucs", it should be acknowledged though, that they often have no choice but to do so, because much of theoretical inguistics as it has come to dominate the field in the twentieth century does not really inform these other fields very well

2 In another dimension - takıng theorıes of scientufic knowledge and of language as parts of cognitive science - other interesting connections can be established between the Kuhnian view of science and the cognitive view of language For example, the contents and structure of the notions "paradigm" and "prototype" exhibit many parallels It is not possible to elaborate that point here, but cf Geeraerts (1985a)

3 Part of the redson for undertaking this research was my involvement in developing and teaching new composition courses, both for college students and for (government) employees, within the framework of the Taalcentrum-VU ("Free University Language Center") I want to thank my Taalcentrum colleagues Rob Doeve and Margreet Onrust for their contributions to the discussions in this project

4 Laudan only distinguishes between internal and external problems within the class of conceptual problems, not within the class of empirical problems In my view, there is no principled distinction between (in)consistency with the rules of another scientific field (Laudan's idea of an external problem) and (in)consistency with those of some other cultural practice Cf Elffers (1991 esp 148-151) for a critical apprasal of Laudan's distinction between empirical and conceptual problems in the context of a study in the history of linguistics

5 I will gloss the occurrences of worden with 'be(come)', and those of $z u j n$ with 'be', in order to make it maximally clear which particular passive auxiliary is involved No claim is implied about translatability into idıomatic Englısh

6 A specidl note for redders familar with German the past form of Dutch worden is werden, $1 \mathrm{e}$ a form of which the spelling (but not the pronunciation) is identical to the form of the German passive auxilary in the present, while the Dutch present form worden is most reminiscent of German wurden, which is past Furthermore, German werden may dlso be used as a future auxilıary, whereas Dutch has zullen

7 But not all combinations of $z y n$ and participles are passive for certain verbs $z y n$ is the ordinary auxilary for the perfect Piet is gevallen medns 'Peter has fallen' See Shannon (in press) for discussion of the factors involved in the choice of duxiliary

8 The forms aan het + infinitive and bezlg te + infinitive, sometimes cited as Dutch equivalents of the progressive (cf Kirsner 1985, Boogaart 1991), present a process in such a way that its end is not envisaged, which makes is rather different from the English progressive and especially strange in combination with the passive A sentence like $D e$ vloer was gepoetst aan het worden, if acceptable at all, evokes a number of "strange" connotations, apparently unlike an English progressive passive such as The floor was being polished

9 Agdin, for readers familiar with German note that German has two forms (sind gesungen and sind gesungen worden), where Dutch has only one It is true that tedchers often use d trick of adding the past participle geworden to d sentence with the duxiliary $z l j n$ for purposes of "disambiguation", $1 \mathrm{e}$ in order to teach the students to label such a sentence on one occdsion as "passive" (when the addition is possible) and on another ds "dctive", however, this usage is highly artificial

10 Shibatan (1985) argues (e $\mathrm{g}, 1985$ 837) that cross-linguistically, the passive prototypıcally functions to "defocus" the agent rather than to "promote" the patient (cf also 
Langacker 1991812 ) This view is an improvement, but I think it is not sufficient to characterize the whole range of passives, in particular the differences among them

11 The active counterparts of some of these examples (espectally 11 and 12) may, depending to some degree on the context, sound d bit awkward in the case of (11) the subject would contain an indppropriately long relative clause, and in the case of (12) the pain might be felt to become personified (taking on some features of prototypical subjects, in terms of Van Oosten 1986) This does not, of course, prevent these sentences from being "counter-examples" to the general claim that the agent in a passive is "deemphasized"

12 Kirsner (1976a, 1976b) is the only author who specifies his notion of "attention" in such a way that only "topıcs" ( 1 e surface subjects) fall under it, so strictly speaking, sentences like (10)-(12) provide "counter-examples" to all the other andlyses But even in Kirsner's specified analysis, it remains unclear what the relation is between the use of the notion "dttention" for topics and its at least equally well founded use for new information So I think the notions of "attention" and "emphasis" should be eliminated from the grammatical characterization of the passive, (for similar arguments involving word order, see Verhagen 1986, 1987) This is not to say that the function of the pdssive (or word order, for that matter) is never related to something like emphasis, but only that the function of language elements must be characterized in more specific terms than just "plus/minus emphasis" or "more/less attention" - if only to avoid ending up with a grammar in which everything would be either an emphasizing or a de-emphasizing device Linguistic instruments are (and must be) more specifically functiond than that

13 Taken literally, the advice in the textbooks implies that perfect passives, since they are passives, should often be transformed into active formulations, fortunately for the students (and significantly in view of my criticism), the examples provided to illustrate this advice involve almost without exception only worden-passives

14 Note that the first of the two alternative phrases mentioned, involving a te-infinitive, is to be translated into English with a passive formulation 'is to be found'

15 But note that this is not completely arbitrary also in the non-pdssive uses of the verbs worden and zijn any nominal element construed directly with one of them is never an agent Though I will not pursue the issue here, it is therefore easily conceivable that this aspect is part of a higher level schema generalizing over all uses of both verbs But even in that case it could still very well be directly associated with the passives as such, too An important argument supporting this latter view is the existence of impersonal passives of the type Er werd/was gelachen (lit 'There be(came)/was laughed', $1 \mathrm{e}$ 'There was/had been laughter', cf Ktrsner 1976a, 1976b) This usage, without any core participant indicated but with an implication of an agent, is specific for the passive, it does not occur with worden and zlyn in general we do not say *Er werd/was zlek" (hit 'There was ill'), for 'There was ıllness', 'People became/were ill' Cf also the discussion of examples (22)ff in the text

16 "Change" (of place or condition) is centrally involved in the Transitivity parameter KINESIS, of Hopper and Thompson (1980 285)

17 A further extension of such a network description could conceivably consist in analyses for combinations of hebben 'to have' + past participles (the most common form for 'perfect tense'), krijgen 'to get', 'to receive' + past participles (indirect object passive, as well as certain kinds of 'achievements', as in lets gedaan krijgen 'to get something done', and a number of other verbs (cf ANS 1984 527-531) I will not pursue that possibility here, since it far exceeds the area of the passive 
18 Interestingly, most subordinate clauses in the Eindhoven Corpus with "semi passives" involving the be-like verbs staan, etc, have the order which, according to the analysis proposed in Pardoen (1991, in press), is the most stative one (the participle preceding the finite verb)

19 Cf Duinhoven (1988 279) "[Worden/zunn+ past participle] has been reinterpreted as a unit, as one abstract form Active and passive are opposite forms of the same verb" (my translation, AV) Duinhoven's explicit statement is reminiscent of De Groot's $(1949136,141)$ edrlier claim that worden as a passive duxiliary is an element of the verbal paradigm, just like (in his view) the perfect duxiliaries hebben 'have' and zijn 'be', whereds worden as a copuld belongs to d different word cldss Twentieth-century grammars of Dutch (culminating in the ANS 1984 esp 525-526) simply assume two distinct word classes "copuld" and "passive duxilidry", both with the string worden ds a member, without even discussing the possibility of a connection between the meanings of these two elements At the end of the nineteenth century, Den Hertog (cf 1973 184) had expressed a view that is somewhat closer to mine he clamms that the passive meaning in a passive sentence does not derive from the use of worden, ds this only indicates "entering [ ] into the state, designated by the participle", though he does classify it as belonging to another word class than worden in its copular uses

20 As indicated in note 6 , the German verb werden is used as a passive auxilary too, when combined with a past participle When combined with an infinitive, German werden functions as an indication of future (where Dutch uses zullen) On the one hand, this is another natural extension of the basic meaning to become, but on the other hand, it is clear that this basic meaning does not suffice to predict the dctual uses of the word in one language or another

Similar comments apply to the differences between Dutch and English One of the senses of the perfect participle in English distinguished by Langacker (1982, 1991 521 ) is one that profiles all the states involved in a process, including but not limited to the end state, this is the "processud", 1 e passive use of the participle, for example destroyed in The town was destroyed house by house (abbreviated as $\mathrm{PERF}_{3}$ ) Notc that the difference that Langacker sees as a difference in the use of the partıciple, in Dutch corresponds to d difference in the auxiliary those clauses which have d PERF accord- $_{3}$ ing to Langacker's andlysis, have the duxiliary worden in Dutch Since this duxiliary is itself processual in the relevant sense, it scems unnecessary to dssume PERF 3 for Dutch Note also that the Dutch equivalent of English sentences like $A$ wagon train attacked whule crossing the pratrle would always form a curcle (cf Langacker 1982 62) cannot use the participle construction, and must be translated with a full relative clause, including the verb worden Thus, there are severd indications here that $a$ comprehensive grammatical description has to involve both lower and higher levels of generalization we must be able to explicate both the resemblances and the contrasts between related elements in different languages

21 Witness the papers about copula vs auxiliary and nominal vs verbal predicate in Hoogteljling's (1968) anthology Cf Pdrdoen (1991, in press), for discussion

22 Van Oosten (1986 195) correctly observes that the exercise of "comparing the passive with its active counterpart", being a resedrch exercise, "is at best artificidl and at worst misledding The central premise is that a spedker or writer is faced with the decision whether to use the active or the passive In fact, of course, that is not true " Speakers do not plan an enture sentence ahead of time and then choose the participant to encode as the subject, rather, they generdlly come out with a subject and then go on to tack an appropriate predicate to it (Van Oosten 1986 197)

23 I am grateful to an anonymous reviewer for bringing this to my attention 
24 Passive is therefore sometimes a good translation for a Dutch object fronting sentence, given the restrictions on simple fronting in English For discussion of the ddvantages and disadvantages of this strategy in particular instances, see Hannay and Mackenzie (1990 212)

25 As for English, the comprehensiveness of this characterization may be questioned in view of so-called continuous perfects as in We have lived in London since last September (ct Beedham 1982 88) For Dutch, the characterization is adequate anyhow For the purpose of text analysis, a more useful characterization of the perfect is "looking back on event/situdion" (cf Dadlder and Verhagen in press) This is not incompatible with the above characterization, though, concelvably, the latter is the correlate of the former on the level of the event/situation designated by the sentence

26 Which, of course, are themselves very different from theoretical expositions about passive and transitivity, even though they are inspired by the theory $\mathrm{Cf}$ the final remarks in section 1

27 Other spontaneous strategies included insertion of er 'there' initially and the use of gaan "to go" as a kind of future auxilıdry After some explicit discussion, several subjects also applied the strategy of replacing the passive of action verbs by the active form of more stative verbs

- 28 In line with the andlysis proposed in this paper, the reference to the agent has been omitted in the revision In view of the function of the text (informing the readers of what to do in certain circumstances), this is completely justufied, especially under the assumption that the text stems from the insurance company itself In another context, omittıng such a reference might not be a good idea As an example, consider an article in a consumer's magazine, comparing the conditions imposed by different insurance companies Then the purpose of the text is not to help the reddel decide whether to sign a policy (an activity in which the insurance company is not a participant) but to help him choose between companies (where it obviously is) Clearly such a text would require a different kind of formulation in several distinct respects

- 29 Depending on the wider context, another alternative could be the removal of the unclanty about the agent, and simply writung "I assume" The question on which this depends is whether the writer of this text more generally refers to him-/herself in places in the text where "decisions" are involved

\section{References}

Aarts, F G A M and H Chr Wekker

1987 A Contrastive Grammar of English and Dutch Leiden Nijhoff

ANS

1984 Algemene Nederlandse Spraakkunst Onder redactie van G Geerts, W Haeseryn, J de Roolj, M C van den Toorn Gronıngen/Leuven WoltersNoordhoff

Beedham, Christopher

1982 The Passive Aspect in English, German and Russian Tubingen Narr

Boogaart, Ronny

1991 "Progressive aspect" in Dutch In Drijkoningen, Frank and Ans van Kemenade (eds), Lingulstics in the Netherlands 1991 Amsterdam/Philadelphid Benjamins, 1-9 
Brederode, Tom van, Willem Koopman and Allan James

1990 A Key to Better English An Advanced English Grammar voor [sıc] Dutch Speakers Muiderberg Coutinho

Chilton, Paul and George Lakoff

1989 Foretgn pohcy by metaphor Center for Research in Language Newsletter (Unıversity of Calıforna, San Diego) 3(5), 5-19

Comre, Bernard

1981 Aspect and voice Some reflections on perfect and passive In Tedechi, $\mathrm{Ph}$ and A Zaenen (eds), Syntax and Semantlcs 14 Tense and Aspect New York Acddemic Press, 65-78

Cornelis, Lourse $\mathrm{H}$

1990 Patient SSH wordt behandeld tegen passivitis Unpublished ms, Vrije Unıversitert Amsterdam

Dadlder, Saskıd and Arıe Verhdgen

in press Dutch tenses and the analysis of a literary text The case of Margd Minco's . De Val In Kirsner, Robert S (ed)

Duinhoven, A M

1988 Passief en zinsfasering Forum der Letteren 29, 268-287

Elffers, Els H C

1991 The Historlography of Grammatical Concepts 19th and 20th-Century Changes in the Subject-predtcate Conception and the Problem of Thetr Historical Reconstruction Amsterdam/Atlanta Rodopi

Geeraerts, Dirk

1985a Paradigm and Paradox Investigations into a Paradigmatic Theory of Meaning and its Epistemological Background Leuven Unıversitare Pers

$1985 b \quad$ Les donnees stereotypiques, prototypiques et encyclopediques dans le dictionnaire Cahters de Lexicologie 46, 27-43

1988 Where does prototypicality come from? In Rudzkd-Ostyn, Brygida (ed), 207-229

Groot, A W de

1949 Structurele Syntaxis Den Hdag Servire

Hannay, Mike and J Lachlan Mackenzie

1990 The writing student From the architect of sentences to the bulder of texts In Nash, W (ed), The Writing Scholar Studies in Academic Discourse London Sage, 205-235

Hermans, Willem Frederik

1951 Het behouden huts Amsterdam De Bezige B 1 ]

1966 "The House of Refuge" Delta A Review of Arts Life and Thought in The Netherlands 9 (3), 31-66 (Reprint of the translation by Estelle Debrot, in Odyssey Review, December 1961 )

Fertog, $\mathrm{CH}$ den

1973 Nederlandse Spraakkunst Derde stuk De leer van de woordsoorten Bewerkt door H Hulshof Amsterdam Versluys [Reprint of the second edition, 1896]

Hoogteijling, Jacob (ed )

1968 Taalkunde in artikelen Groningen Wolters-Noordhoff

Hopper, Paul J and Sandra A Thompson

1980 Transitivity in grammar and discourse Language 56, 251-299 
Janssen, Theo A J M

in press Tenses and demonstratives Conspecific categories In Geiger, R A and B Rudzka-Ostyn (eds), Conceptualtsations and Mental Processing in Language Berlın/New York Mouton de Gruyter

Kursner, Robert S

1976d De "onechte" lijdende vorm Spektator 6, 1-18

$1976 \mathrm{~b}$ On the subjectless "pseudo-passive" in Standard Dutch and the semantics of background agents In Li, Charles N (ed), Subject and Toptc New York Acddemic Press, 387-415

1983 On the use of quantitative discourse data to determine inferential mechanisms in grammar In Kleın-Andreu, F (ed), Discourse Perspectives on Syntax New York Academic Press, 237-257

1985 Quantitative approaches to Dutch linguistic structure In Fleitcher, William $\mathrm{H}$ (ed), Papers from the First Interdisciplinary Conference on Netherlandic Studies Lanham, MD University Press of America, 95-104

- Kirsner, Robert S (ed)

in press The Netherlands and Beyond [Selected Papers from the 5th Interdisciplinary Conference of Netherlandic Studies at UCLA, July 1990] Lanham, MD University Press of America

Kuhn, Thomas S

1970 The Structure of Scientific Revolutions (2nd edition) Chicago University of Chicago Press

Langacker, Ronald W

1982 Space grammar, analysability, and the English passive Language 58, 22-80

1987 Foundations of Cognitive Grammar Volume I Theoretical Prerequistes Stanford, CA Stanford University Press

1988 A usage-based model In Rudzka-Ostyn, Brygidd (ed ), 127-161

1990 The rule controversy A Cognitive Grammar perspective Center for Research in Language Newsletter (University of California, San Diego) 4 (3), 4-15

1991 Foundations of Cognitve Grammar Volume II Descriptive Application Stanford, CA Stanford University Press

Langacker, Rondld $\mathrm{W}$ and Pameld Munro

1975 Passives and therr meaning Language 51, 789-830

Laudan, Larry

1977 Progress and Its Problems Towards a Theory of Sctentufic Growth London Routledge and Kegan Paul

Nedjalkov, Vladımır P and Sergej Je Jaxontov

1988 The typology of resultative constructions In Nedjalkov, V P (ed), Typology of Resultative Constructions (English translation edited by Bernard Comrie) (Typological Studies in Language 12) Amsterdam/Philadelphia Benjamins, 3-62

Onrust, Margreet $G$

1988 Eindverslag ZWO-project 300-163017 Unpublished ms, Vrije Universiteit Amsterdam

in prep De topic-zin

Oosten, Jeanne van

1986 The nature of subjects, topics and agents A cognitive explanation Bloomington Indiana University Linguistics Club 
Overdum, Boudewijn

1986 Rapporteren (Auld 133) n p Spectrum

Pardoen, Justme A

1991 De interpretatie van zinnen met de rode en de groene volgorde Forum der Letteren 32, 1-22

in press The word order of findl verbal elements in Dutch Free variation or meaningful organizdtion? In Kirsner, Robert S (ed)

Prince, Ellen F

1981 Topicalization focus movement, and Yiddish-movement A pragmatic differentudion In Alford, DK et dl (eds), Proceedings of the Seventh Annual Meeting of the Berkeley Linguistucs Soctety Berkeley, CA Berkeley

Renkemd, Jdn Linguistics Society, 249-264

1979 Schriffwyzer 's-Gravenhage Staalsuitgever1]

1981 De taal van Den Haag een kwantitattef-sthlistisch onderzoek naar aanletding van oordelen over taalgebrulk 's-Gravenhage Stadtsuitgeverij

1989 Schrlfwizer (revised edition) 's-Gravenhage SDU Uitgeveri]

Rice, Sally A

1987 Towards a cognitive model of transitivity Doctoral dissertation, University

Rorty, Richard of Calıfornia San Diego

1989 Contingency Irony Soludarty Cambridge Cambridge University Press

Rudzka-Ostyn, Brygrda (ed)

1988 Toptcs in Cognitive Linguistcs Amsterdam/Philadelphld Benjamins

Shannon, Thomas $\mathbf{F}$

in press Hamlet in Holland To be or not to be in Dutch A cognitive account of

Shibatani, Masdyoshi

some puzzling perfect auxiladry phenomena In Kirsner, Robert S (ed)

1985 Passives and related constructions A prototype andysis Language 61,

Turner, G W

1973 Stylestes Harmondsworth Penguin

Turner, Mark

1987 Death is the Mother of Beauty Mind Metaphor Crittcism Chicago The

University of Chicago Press

Uit den Boogdart, P C (ed)

1975 Woordfrequenties in geschreven en gesproken Nederlands Utrecht Oosthoek,

Scheltema \& Holkemd

Verhagen, Arie

1986 Lingulstle Theory and the Function of Word Order in Dutch Dordrecht Foris

1987 On certain functional approdches to word order In Beukema, Frits and Peter Coopmans (eds), Linguistics in the Netherlands 1987 Dordrecht For1s, 215222

1990 De interpretatiestructuur van passieve zinnen Forum der Letteren 31, 81-92 